\title{
MITOS GREGOS NO TEATRO BRASILEIRO DOS ÚLTIMOS 30 ANOS
}

\section{GREEK MYTHS IN THE BRAZILIAN THEATRE OF THE LAST 30 YEARS}

\author{
Carlinda Fragale Pate Nuñez \\ Universidade do Estado do Rio de Janeiro, Instituto de Letras, Rio de Janeiro, RJ, Brasil
}

Resumo: A experiência exílica é uma tônica em peças brasileiras recentes de tema mítico. Baseado na Trilogia perversa (BENDER, 1986), em Ismene, Princesa de Tebas (SENNA, 2006) e n' O Olimpo carioca (BRANDÁO, 2012), o artigo mostra que os mitos antigos, enquanto mapeiam problemáticas palpitantes para a época em que eles retornam (o páthos do imigrante, do perseguido político e mesmo da cidade tida como refúgio ideal para problemas "olímpicos"), funcionam como o "tiroir à double entrée" de que fala Espagne (1999, p. 78): não são apenas pontos de passagem entre culturas, mas deflagradores de "itinerários da memória" (ESPAGNE, 1999, p. 138).

Palavras-chave: teatro mítico; transferência cultural; experiência exílica.

Abstract: The exile experience is a trend in recent Brazilian theatre which makes use of mythical themes. Based on The Perverse Trilogy (BENDER, 1986), Ismene, Princess of Thebes (Senna, 2006) and The 'Carioca' Olympus (BRANDÁO, 2012), this article shows that while ancient myths map questions related to the period in which they return (the immigrant pathos, the politically persecuted individuals, and even the city regarded as the ideal refuge from "Olympic" troubles), they also act as the "tiroir à double entrée" mentioned by Espagne (1999, p. 78): they are not mere crossing points between cultures, but they are also triggers of "itineraries of memory" (ESPAGNE, 1999, p. 138).

Keywords: mythical theatre; cultural transfer; exilic experience.

\section{Premissas para sabermos onde queremos chegar}

Mitos de extração clássica chegaram ao Brasil com as caravelas. A semeadura da herança clássica confirmaria náo só com frutos da terra a profecia de Pero Vaz de Caminha (Carta de Achamento, 1500) de que, em solo brasileiro, "tudo dá": as imagens de uma natureza prodigiosa e de seres sobre- e infra-humanos que os navegantes já traziam consigo (HOLANDA, 2010) foram as sementes para processos de aclimatação, 
sincretismo, mestiçagem e hibridização cultural (BURKE, 2003); adaptação e apropriação (HUTCHEON, 1995; SANDERS, 2006); intertextualidade, paródia (RODRÍGUEZ MONEGAL, 1980; RODRÍGUEZ, 2001; 2002), reescritura, tradução linguística e cultural, transcriação (CAMPOS, 1992), que não cessaram de germinar entre nós.

Negociaçóes nos planos do imaginário e do contato material entre literatura oral e escrita, popular e erudita, amalgamando diferentes tradiçóes e aguçando suas contradiçóes, preservaram e robusteceram tanto o substrato mítico nativo quanto o importado. No que diz respeito ao Brasil, temas mitológicos e demais insumos da cultura humanística europeia participaram, desde os primórdios da colonização, do audacioso processo de transplantaçáo cultural ocorrido durante o expansionismo dos povos em direção ao Atlântico Sul, e continuam assomando como dispositivos do campo artístico, até os dias atuais (NUÑEZ, 2003, p. 219-259).

Alguns pressupostos teóricos nos guiam, na abordagem da presença do mito em obras recentes do teatro brasileiro que vamos aqui desenvolver. $\mathrm{O}$ primeiro nos adverte para o fato de que as transformaçóes da herança clássica se incluem no quadro das trocas culturais, em geral: elas decorrem de encontros historicamente determinados entre sistemas de referência heterogêneos. $O$ segundo especifica o primeiro, já que o processo de transferência cultural aqui focalizado é peculiar: não dá lugar a açóes recíprocas (afinal, a atualização do legado greco-latino se verifica em tempos pósteros, determinando um processo de assimilação, a princípio, de mão única ${ }^{1}$ ), nem contínuas (de fato, a transferência acontece de forma intermitente, marcada pela descontinuidade temporal e sujeita à ação de fontes intermediárias). Neste trabalho, não dissociamos o mito da função de privilegiado dispositivo de transferência cultural. Como narrativa de imediata e eficiente comunicação, ele age como mediador entre pessoas e entre campos epistemológicos, valendo-se de um espaço intermédio comum e permitindo que imbricaçóes culturais ocorram ao modo de uma memória latente.

Nosso terceiro pressuposto se apoia em Michel Espagne, para quem "Uma transferência cultural é um tipo de tradução, já que corresponde à passagem de um código a um novo código" (ESPAGNE, 1999, p. 8). Em outras palavras, situamos a literatura de extração mítica no espaço liminar entre estudos comparativos de adaptação e de tradução cultural, sem que

\footnotetext{
${ }^{1}$ Diferentemente do que ocorre nas trocas culturais, que se dão sincronicamente entre duas culturas em contato, a única possibilidade de modificação do passado pelo presente surge da descoberta de fatos e/ou documentos, ou novos modos de compreensão do legado clássico.
} 
ela se ligue exclusivamente a um ou a outro âmbito. Este duplo vínculo deriva das próprias recriaçôes, adaptaçóes e traduçôes, que não pertencem integralmente a um autor, no sentido que se dá à autoria de outros textos. Por causa do agón autoral entre o escritor e seus adaptadores, o reprocessamento artístico de um tema, obra ou mito se apresenta necessariamente como local de contestação ideológica, onde entram em choque autores, culturas, épocas, ideias e meios de expressão. Como o afirma Slavoj Žižek (2014, p. 6), "uma das melhores maneiras de detectar mudanças na constelaçấo ideológica é comparar 'remakes' consecutivos de uma mesma história".

Por outro lado, uma visão atualizada dos Estudos Clássicos não pode ignorar, tanto do ponto de vista epistemológico quanto da arte, a arguta observação de José Luís Jobim: "as questôes e temas evocados como herança e memória serão as que julgamos (ainda) relevantes agora, e são enfocadas a partir de teses, teorias, perspectivas que estáo vigentes agora" (JOBIM, 2009, p. 102). Ou seja, uma mesma história contada de forma diferente, em adaptação ou recriação, pode ilustrar mudanças na constelaçáo ideológica; ou, fiel ao texto precursor, ilustrar um retorno nostálgico a uma condiçáo ideológica passada; ou ainda recuperar uma vertente ideológica inobservada ou mesmo desconhecida, mas presente num texto-fonte, que se perde, em adaptaçóes ostensivamente concentradas na narrativa ou em consideraçóes estéticas. Este é o quarto e último pressuposto que nos interessa registrar, assinalando, todavia, que é deste lugar, da captação do que os mitos silenciaram, no seu passado distante, e só se deixa pronunciar em línguas estrangeiras, dicçóes futuras e lugares estranhos à sua origem, que se tornam visíveis o essencial do mito (sua condiçấo oracular e sua funcionalidade prática para as sociedades que o adotam) e o inesperado da história.

\section{Lidando com as obras}

A retomada do temário antigo no teatro brasileiro contemporâneo confirma a tendência do teatro universal de mapear problemáticas palpitantes para a época em que os mitos retornam. As peças de tema mítico que reaparecem nos palcos brasileiros dos últimos trinta anos evocam, direta ou indiretamente, a experiência exílica. Constatamos a persistência desta questão na Trilogia perversa (1986), adaptação gaúcha da maldição dos Atridas por Ivo Bender, em Ismene, Princesa de Tebas, de Pedro de Senna (2006), e na Revista do Ano - O Olimpo carioca, de Tânia Brandão (2012). Tragédia e comédia antigas se reatualizam, nos contextos históricos da imigração alemã para o sul do Brasil, da emigração de cidadãos perante 
um cenário político em crise e da paródica posição do Rio de Janeiro como refúgio ideal para problemas "olímpicos".

O teatro brasileiro de tema greco-romano se consolidou, ao longo do século XX, por meio de obras que se tornaram emblemáticas tanto da eficaz absorção do clássico quanto de engenhosas formas de adaptação do antigo aos palcos modernos. Em sua maioria, as reapropriaçóes brasileiras da herança clássica se prestaram a reformulaçóes radicais, quase desfiguraçóes da matriz grega ou romana, devidas à frequente nacionalização das problemáticas, à mudança de nomes das personagens e à hibridação de formas.

\section{Trilogia perversa}

O gaúcho Ivo Bender ${ }^{2}$ destaca-se, na dramaturgia de extração mítica dos últimos trinta anos, por ter concebido uma Trilogia perversa (1988), a exemplo da única trilogia remanescente do teatro grego, profundamente trágica, porém sui generis. Quanto ao tema, a mítica maldição dos Atridas é transplantada para o sofrido contexto da imigração alemã, no Rio Grande do Sul; quanto às personagens, têm nomes brasileiros ou alemães, misturando pessoas comuns e figuras históricas, em três peças que se intertextualizam com a Oréstia de Ésquilo (458 a.C.), a Electra de Sófocles e quatro tragédias $^{3}$ de Eurípides, sobretudo, a Ifigênia em Áulis (405 a.C.). Mas as fontes gregas e o modelo trilógico são submetidos a um reordenamento, na trilogia brasileira, primeiramente em virtude de seleção diferenciada dos nódulos míticos para cada peça e, ademais, pela progressão temporal inversa.

A disputa entre dois irmãos pelo cetro atrida e o sacrifício de uma filha por seu pai são os antecedentes míticos que motivam os acontecimentos da Oréstia: na primeira peça da trilogia grega, a mãe inconformada se vinga, matando o marido infanticida; na segunda peça, os filhos do rei morto o vingam, matando a própria mãe; e na terceira peça, o matricida é perseguido,

\footnotetext{
${ }^{2}$ Ivo Bender começou sua trajetória como autor dramático em 1961 com a peça As cartas marcadas. Desde então, escreveu Queridíssimo canalha (1971), Quem roubou meu anabela? (1972), Sangue na laranjada (1978) e Mulheres Mix (2001). Também publicou traduçóes para o português das tragédias Fedra, Ifigênia e Tebaida, de Jean Racine, e trabalhos nas áreas de teoria e crítica teatral: Comédia e Riso - uma Poética do Teatro Cômico (Editora da UFRGS/EDIPUCRS, 1996) e Açáo e Transgressáo - três ensaios sobre tragédias de Sófocles, Eurípides e Racine (Editora da UFRGS, 1991). Atualmente é professor aposentado de Artes Dramáticas da Universidade Federal do Rio Grande do Sul. Para mais informaçóes, cf. Revista BENDER, Ivo. Autores gaúchos, v. 3. Porto Alegre: Instituto Estadual do Livro, 1984.

${ }^{3}$ Orestes (408 a.C.), Electra e Ifigênia em Táuris (sem datas definidas: a primeira foi encenada entre 420 e 410 a.C.; a segunda, por volta de 414 a.C.).
} 
julgado e absolvido por um tribunal, numa ordenação paralelística e cronológica dos fatos. Já na Trilogia perversa, fatos históricos e a memória de colonos germânicos no sul do Brasil se imiscuem na trama grega, o que gera um efeito recíproco de contaminação mítica do histórico e factualização do mítico. Cada peça tem como título o ano em que ocorrem os fatos encenados: a primeira, $\mathbf{1 9 4 1}$, tematiza um matricídio que se reporta àquele perpetrado por Orestes e Electra contra Clitemnestra; a segunda, 1874, tem por base o sacrifício de Ifigênia determinado pelo pai, Agamemnon; a terceira, 1826, revive, no Brasil meridional, as disputas entre Atreu e Tiestes, primeira geração humana em que se consuma a maldição familiar.

Essas datas remetem, retrospectivamente, a situações fartamente documentadas: 1941, a uma grande enchente em uma zona germânica do Rio Grande do Sul; 1874, ao fim da Revolta dos Mucker ${ }^{4}$ e ao assassinato de Jacobina Maurer, líder messiânica do movimento junto a seu marido, João Jorge Maurer, um Wunderdoktor (curandeiro que realizava prodígios com ervas), e 1826 remete ao início da colonização alemá no Estado. A partir desses fatos verídicos, exumados a propósito de um matricídio (na primeira peça), do sacrifício de Teodora (na segunda) e da rivalidade entre irmãos (na terceira), núcleos temáticos da maldição dos Atridas, a Trilogia brasileira se "descola" da matriz grega por meio de dois dispositivos: a cronologia invertida e a reciclagem geopoética do mito. Inverte-se a lógica do trágico grego, na qual o mito prevalece sobre a história; subverte-se a ordenação temporal do modelo grego; historicidade e geograficidade se convertem em elementos que fazem os nexos entre os (suplícios dos) tempos míticos e os da colonização sul-rio-grandense. Com estes três elementos, Bender estipula o princípio gerenciador da toda a trilogia: a perversão - mítica, histórica e poética.

Em 1941, encarnaçôes de Electra e Orestes atuam num sítio de colonos

\footnotetext{
${ }^{4}$ Cf. Janaína Amado, “A revolta 'mucker' ocorreu entre 1868 e 1874 em São Leopoldo, a primeira colônia alemã fundada no Rio Grande do Sul, prolongando-se até 1898. A palavra 'mucker' era usada como sinônimo de 'beato', 'fanático', 'santarrão'. Assim os adversários designavam, na época, pejorativamente, os rebeldes. A revolta envolveu imigrantes alemães que se reuniram em torno do curandeiro Joấo Jorge Maurer e de sua mulher Jacobina, inicialmente para obter esclarecimentos e, mais tarde, com fins religiosos." Foram perseguidos e presos, mas libertados por falta de provas. Em 1874, adeptos de Jacobina promoveram um ataque em massa contra seus principais adversários. A Guarda Nacional ocupou a regiáo, mas os rebeldes resistiram. "A 2 de agosto de 1874 a maior parte dos 'mucker' foi morta; os restantes foram condenados. Os impronunciados mudaram-se para outras colônias onde, anos depois, foram trucidados pela população local." (AMADO, Janaína. Conflito social no Brasil: a revolta dos “Mucker”. São Paulo: Símbolo, 1978. p. 18-19).
} 
alemães durante o evento calamitoso da Grande Enchente ${ }^{5}$; em 1874, imigrantes alemães vivem no Brasil como apátridas, desnacionalizados/ desnaturalizados, razão pela qual se lançam à conquista de direitos civis, delirando fundar a Terra Prometida ${ }^{6}$ - Teodora, como Ifigênia, é o cordeiro que os fanáticos imolam à sua causa; em 1826, dois irmãos se amotinam contra um terceiro irmáo, revestindo de um primitivismo germânico a ferocidade de Atreu e Tiestes.

As três peças são medonhas. Bender vai muito além do paralelismo com as fontes gregas. Reinventa o trágico a partir de enredos originais, abordando aspectos do passado colonial no Rio Grande do Sul, em si carregados de tragicidade, porque o páthos da vida e da morte neles claramente se mesclam. A hybris do imigrante transparece na força quase elemental que lhe permite sobreviver; colonos, falando uma língua estranha, sem recursos materiais, nem referências locais, impelidos por forças sociais e inconscientes, praticam a hamartía (erro trágico) de rivalizar com a natureza e o meio que, àquela altura, os rechaçava; as falas são claras, mas ocultam motivaçóes nubladas. Nesse território inóspito, em que o outro é o ameaçador/ameaçado, Bender moldou protagonistas no qual o agón das trocas e acomodaçóes culturais se trava às custas da mescla entre história e mito.

\section{Ismene, Princesa de Tebas}

Pedro de Senna focaliza a maldita família de Édipo, com a inusitada ideia de retirar Ismene das sombras que lhe couberam como herança do glorioso teatro ateniense. A maldição dos labdácidas foi mais pesada para a simplória irmã de Antígona, que atravessou inglória toda a era pós-clássica. Um solilóquio apenas lhe foi dedicado pelo poeta grego contemporâneo Yannis Ritsos ${ }^{7}$ (2012). Nada mais, até 2006.

\footnotetext{
${ }^{5}$ Esta enchente foi a maior calamidade natural ocorrida no estado do RS, então com menos de 3 milhóes de habitantes. As chuvas iniciaram em abril de 1941 e se estenderam por mais de três semanas, deixando $25 \mathrm{mil} \mathrm{km}^{2}$ do estado submersos e um contingente de 80 mil flagelados somente na capital. A enchente permanece viva até hoje na memória popular dos gaúchos. A expressão "abobado da enchente" (que significa "abestalhado"), muito conhecida dos gaúchos, teria surgido devido ao famoso cataclisma.

${ }^{6}$ Jorge Andrade realizou projeto semelhante em Vereda da salvaçáo (1958), peça que aborda um fato verídico: a repressão policial e morte de camponeses, fanáticos religiosos de Catulé, em Minas Gerais, em abril de 1955. A problemática social se entretece, nessa peça, com o mito de Édipo.

7 Ritsos, poeta lírico e dramático grego (1909-1990), recriou o páthos da tragédia grega em diversos títulos que retomam mitos, lendas e paisagens antigas. Ismene é um dos seus solilóquios dramáticos.
} 
A filha de Édipo manteve-se como "mulher sem qualidades", signo de uma ausência, na tradição a que pertence. Ineditamente, essa situaçáo muda, com Pedro de Senna, dramaturgo brasileiro, que percebeu exatamente nesta condição de sombra a situação ideal para torná-la protagonista de uma tragédia pós-moderna. A vida em negativo, como significante ao qual não se agregou nenhum significado, traduz a patética insignificância que a promoveu à exata situação de protagonista da atualidade.

Pedro de Senna, nascido no Rio de Janeiro em 1975, mas residente na Inglaterra desde 2001, angariou um respeitável currículo ligado às artes cênicas e ao dramático. É professor universitário, tradutor, ator, dramaturgo e diretor de teatro. Com essa bagagem, o dramaturgo concebe o novo drama sobre a diatribe tebana. Tebas está na iminência de uma invasão. Creonte expia, demente, a responsabilidade pela morte de todos os seus familiares. Generais tomaram as rédeas da pólis. Sem poder, sem filhos, sem mulher e sem juízo, o rei vive acossado por espectros. O Coro de mortos tebanos lamenta o novo infortúnio sobre Tebas. Ismene se aconselha com Tirésias, que encara com ceticismo os próprios dons proféticos, outrora indubitáveis e prestigiosos: a voz da resistência no passado se apresenta como arauto da desistência no presente: "eu náo quero mais"; "estou cansado disso tudo; eu quero que se acabe / paz". O velho adivinho reconhece Ismene como "intocada pela maldição". Todos os labdácidas estão mortos, à exceção dela, que se vê diante de um dilema: para salvar a cidade do inimigo, deve entregar-se a um rei estrangeiro e gerar um herdeiro.

A peça retira a figura de um sono milenar para uma dupla tarefa: experimentar a força do trágico em problemáticas atuais e desselar questôes subliminares e mesmo de difícil identificação na peça sofocliana, que pode ser a referência mais evidente e fundamental para a personagem, mas certamente não é a única fonte da peça brasileira.

O tecido dramático da peça se constitui de ressonâncias dos Sete contra Tebas (467 a.C.) de Ésquilo, da Antígona (442 a.C.) de Sófocles, das Fenícias (411 a.C.) de Eurípides, as quais se entrecruzam com citaçóes de Shakespeare e até de Tchekov. Há evidentes importaçóes dos mais importantes conceitos da cultura trágica dos gregos: são vinte e duas referências à hýbris (excedência), como traço da identidade tebana; vinte e cinco, à voragem sanguínea dos labdácidas, capaz de tornar indistintos o sexo e a guerra - a anunciada invasão da cidadela é reiteradamente referida como "estupro de Tebas", assim como Ismene, cujo corpo seria o preço pago pela entrada pacífica do inimigo, se autodenomina a "puta de Tebas"; o castigo imposto a Creonte é tremendo - restar só, como único tebano remanescente 
na Tebas ocupada, um exilado em sua própria terra. A expiação de Creonte, na tragédia moderna, tem dimensôes mitológicas, se recobramos o sentido do exílio para o homem antigo, aqui ressignificado como desterro às avessas.

Alusóes a atitudes covardes ou pusilânimes de Ismene, recontextualizadas no quadro da modernidade, trazem engenhosas reinterpretaçóes capazes de converter as antigas acusaçôes em álibis e até motivos para a valorização da mulher condenada pela tradição:

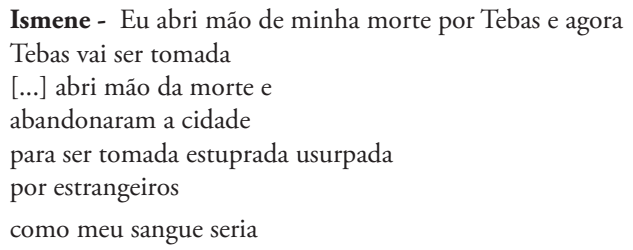

Um mapeamento na linha da transformaçáo da protagonista renderia uma tese. Mas não podemos deixar de referir as situações configurando deslocamentos semânticos, emanaçóes, sutis historicidades, defasagens formais e semânticas que esta Ismene moderna encarna. As assimilaçóes desse tipo nos interessam mais, pois constituem um acesso privilegiado à compreensão do que está sendo culturalmente transferido de um passado a princípio fictício e morto, mas se impóe com energia e sentido bem ativo, na atualidade.

A peça instaura uma temporalidade anterior à própria Grécia clássica. É o próprio tempo mítico, seus eídōla (fantasmas), aqui transformados em kolossoi (colossos), com suas propriedades transcendentes e fenomenais. A concepção do texto recobra o arcaico. Assim, abala a supremacia do clássico como autêntico, para discutir o heroísmo numa perspectiva da modernidade; rompe com o naturalismo, para capturar o primordial, lá onde germina o trágico.

Sem se confundir com qualquer tipo de reconstituição arqueológica, a tragédia de Ismene joga com impulsos primitivos e a centralidade do páthos, numa invenção audaciosa. A Ismene brasileira, no sistema dramatúrgico constituído, não desmente, entretanto, a tradição a que pertence: o medo, a dúvida, o ceticismo, adquirem, porém, uma autojustificação, no horizonte cultural em que ela reaparece (o Coro pontua: "Esta é a tragédia da dúvida / descrença”), já não mais como representante de um éthos (caráter) diminuído, em relaçáo à irmá, mas de um sujeito acossado, num mundo marcado pelo pragmatismo, niilismo, pela reificaçáo das pessoas e dos afetos. 
Em algumas passagens, este páthos moderno se manifesta, ligado a questóes pânicas da atualidade. Ele se expressa na pusilanimidade da Princesa ("Não posso suportar os muros vazios / os fantasmas de minha indecisão"), ao ponto de desestabilizar sintaticamente o seu discurso:

\author{
Ismene - Eu estava decidida \\ tinha decidido \\ estou decidida \\ a nẫo ter filhos \\ ou será isto desafiar os deuses \\ tentar evitar uma maldição \\ que não se pode evitar \\ que não perdoa \\ que não se aplaca \\ que não tem fim
}

Ao contrário do Tirésias da tradição, o da versão brasileira está imerso no niilismo:

Tirésias - Que bem o meu conselho pode fazer,

não sei

nem que bem ele jamais fez

Estou cansado disso

Tebas vai cair e pronto

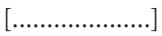

Um plano é o que eles têm e isso basta

o que eu vejo e o que eu não vejo não são nada

eu sou só um velho cego

o que eu digo e o que eu não digo não importam

A Ismene moderna discute tópicos de orientação feminista: a violência contra mulheres, a opção de não ter filhos e a questão do aborto.

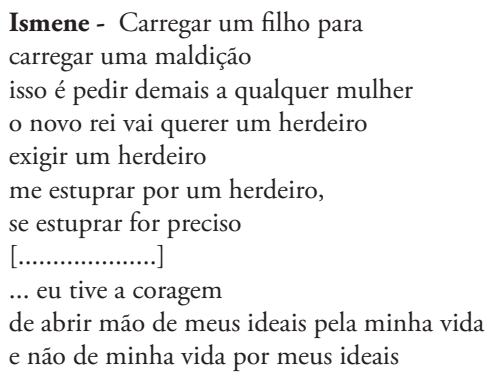


Para compreender a cerebralidade da peça, tem-se de pensar, de alguma forma, como Ismene. É o que diz o Tirésias de Pedro de Senna, em mais de uma oportunidade: "Minha filha, sempre tiveste boa cabeça" (p. 34); "sempre soubeste quando parar". Aqui a reprovação antiga é revertida em louvor. $\mathrm{O}$ dramaturgo náo é nada ingênuo, ao realçar a racionalidade negada a Ismene pelo interesse desde sempre despertado pela grandiosa causa pública e universal de Antígona.

A Ismene razoável e lógica é, aliás, anunciada no célebre e hermético verso de abertura de Antígona, que literalmente se traduz por "Tu és minha

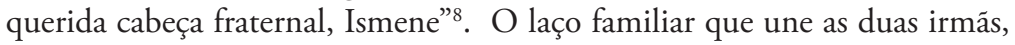
do ponto de vista da Antígona sofocliana, é o pensamento. Quando Ismene demonstra com bons argumentos que é uma temeridade a execução do projeto religioso, Antígona afirma que realizaria o ato piedoso, mesmo ao preço de praticar uma baixeza, num oximoro que associa nobreza e vilania, piedade e baixeza. Em face de tamanha convicção, Ismene adverte Antígona de que está sendo demasiado calorosa com os mortos (a quem ela chama "frios"), insinuação de pendor necrofílico muito clara.

$\mathrm{Na}$ versáo grega, Ismene aconselha a irmã a ocultar seu projeto de enterrar Polinice. Sabia o que estava dizendo. Pela etimologia, Ismene (raiz *eis, *is com o sufixo -men) é "a impetuosa, a vigorosa", o que contraria a atitude da personagem grega. O paradoxo é resolvido por Pedro de Senna: desfaz o descompasso entre sema e soma, nome e corpo, e permite que a personagem passe a honrar sua nomeaçáo, nos palcos brasileiros?.

Outro aspecto a assinalar diz respeito a uma sutileza histórica, discretamente obscurecida, na versão grega de Sófocles, mas que retorna, em primeiro plano, na recriação brasileira: a questâo de purificar a casa real e o solo tebanos. Na peça brasileira, o casamento de Ismene é apresentado como um blefe tramado pelos generais tebanos, para evitar a erradicação do sangue labdácida daquele território. Mas Ismene compreende a estratégia desonrosa do "alto comando", que visa manter isolados não só os descendentes, mas todos os tebanos que tiveram contato com a família de Édipo, inclusive Creonte: questão de prevenção contra o contágio político.

\footnotetext{
${ }^{8}$ Hörderlin, porque perseguia as estruturas do imaginário arcaico e levava a sério o fenômeno da manía (loucura) poética, propôs uma tradução estranha, mas fiel à imagem da cabeça metonímica do pensamento: "Cabeça comum e fraterna! Ó Cabeça de Ismene!" ('Gemeinsamschwesterliches! O Ismenes Haupt?').

${ }^{9}$ A peça se respalda na autoridade de Édipo para explicar o inesperado desencantamento da fraca Ismene. Diz Creonte: "Foi teu pai que escolheu teu nome". A palavra paterna autoriza o protagonismo, ainda que tardio.
} 
Ismene - Eles querem me casar

com o comandante de Argos

Assim ele usurpa a coroa de meu tio -

a coroa de meu pai numa cabeça estrangeira

Ele toma a cidade em paz e poupa o povo

do horror da batalha saque sangue derramado

$\mathrm{Na}$ tragédia de Antígona, é justamente o sangue labdácida que Creonte quer afastar do trono tebano. Para isto, o tirano tinha de curtocircuitar o casamento de Hêmon com a labdácida. Aqui, Creonte é carta fora do baralho; Ismene é destinada a um noivo que não existe de fato.

As irmãs estão em perfeita correlação negativa. O heroísmo de Antígona é sublime; a sublimidade de Ismene é totalmente diferente: ela tem a grandiosidade do pequeno (devaneia, perde-se em reminiscências da infância); a dignidade do fraco ("Não me deixes, tio"); a consciência de si e de seu medo ("Esse é o meu medo"). A última das princesas faz o que qualquer mulher hoje faria.

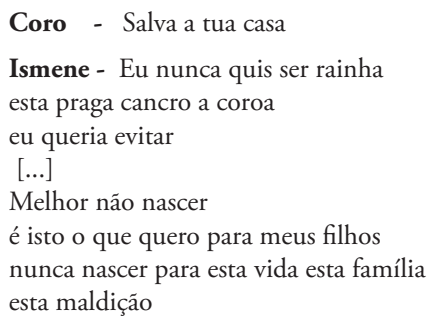

É justamente no influxo de qualidades em negativo que ela se ergue, na peça brasileira, e nega a reificação das relaçóes conjugais, o mercadejamento do seu corpo, a gravidez utilitária.

Em função destes posicionamentos, Ismene nega também a abjeção; conjura apoio para a sua decisão de não gerar filhos para a cidade caótica, sabota o plano do general e sabota o usurpador (diz-se pronta para o contrato matrimonial, mas foge, às escondidas, com Tirésias, os dois últimos a abandonar Tebas).

Através da invenção de um enredo totalmente novo, somos levados a identificar, pelo contraste com o mito antigo, sutilezas táo bem concebidas e camufladas em suas fontes, que podem ter passado irreconhecidas pela crítica, a ponto de se ter fixado a imagem de Ismene apenas como o oposto complementar de Antígona - mas náo foi bem assim. Da mesma forma que a obra atual é capaz de projetar luz sobre a antiga, pode-se raciocinar mirando 
no sentido contrário, prospectivamente: os materiais antigos introduzidos na peça da atualidade funcionam como o elemento anacrônico, na função de tradutor cultural de problemáticas e padróes emotivos que melhor se deixam capturar longe de sua cotidianidade.

De fato, a peça de Pedro de Senna constitui um tipo de assimilação sofisticada do material mítico-dramático, pois joga com uma elaboração estética arcaizante e hierática que leva à dissimilação dos conteúdos antigos.

Se compreendemos a obra como uma peça brasileira que inventa um enredo protagonizado por Ismene, estamos inserindo a protagonista como estrangeira (grega) numa problemática camufladamente tebana e antiga, mas explicitamente pós-moderna. Se entendemos que a peça é a reexperimentação do modelo da tragédia antiga, temos de admitir que Ismene encarna uma figura moderna e falante da Língua Portuguesa surpreendida num conflito e num contexto que lhe são totalmente estranhos - e a peça passa a ser o modo de cristalizaçáo artística das soluçóes possíveis perante impasses existenciais - especialmente o ceticismo moderno. As duas situaçóes combinam, no regime de construção estética do texto e do espetáculo que lhe correspondeu.

A obra dá acesso a uma outra cultura, distante no tempo e muito diferente, com formas de representação e estruturas imaginárias muito diferentes das atuais, mas as adota como meio através do qual o contexto de acolhimento se espelha e se pensa.

Inserida numa surpreendente malha compositiva, entre a rede transhistórica do teatro e o enclave em que ocorrem transferências culturais inusitadas, a tragédia de Ismene revoga o rótulo de simplicidade atribuído à figura mítica, para, bem ao contrário, dar materialidade a complexidades antigas e atuais.

\section{O Olimpo carioca}

Tânia Brandão, dramaturga premiada, historiadora, crítica, professora de Direção Teatral da UNIRIO, envereda pelo caminho da comédia, no melhor espetáculo musical de 2012, A Revista do ano-O Olimpo carioca.

Em meio a uma crise político-social e econômica na Grécia, dois deuses, Hefaísto, Dionísio e uma personagem inventada, a Mulher Labareda (na verdade, disfarce de Ariadne, a esperta princesa que driblou o Minotauro e facultou a vitória de Teseu no labirinto cretense), se mudam para o Rio de Janeiro, a "Cidade Maravilhosa", em busca de uma vida melhor. Ao chegarem, encontram um cenário de desordem, criminalidade, corrupção 
e degradação dos costumes, um estado de coisas muito pior do que deixado para trás.

A peça atualiza o Teatro de Revista, gênero musical e burlesco brasileiro da virada do séc. XIX-XX que comentava os principais acontecimentos de um determinado período. Jogando com múltiplos modelos estéticos, fatos ocorridos na cidade do Rio entre 2011 e 2012 servem de base para uma trama curiosa: de um lado, segue bem de perto os parâmetros da revista do século XIX e de Artur Azevedo (uma cena na praia ecoa a gozação com a hidroterapia de D. Pedro, só que, nas revistas do famoso dramaturgo, a Monarquia é que se banhava); de outro, inspira-se nas revistas francesas e na moda helênica que invadiu o Brasil oitocentista. Por isto, o Olimpo. Mas há ainda uma forma de escrever contemporânea, reinvenção performática da revista ${ }^{10}$.

A qualidade do espetáculo se confirma na coesão de todos os fatores, do enredo à encenação. Tão logo chegam ao Rio de Janeiro, os protagonistas se perdem: Hefaísto vai parar no subúrbio, enquanto Dionísio e Labareda o procuram na zona sul da cidade. A busca dos pares é o pretexto para cobrir a geografia da cidade e oportunizar o encontro de vários personagens, na verdade, alegorizaçóes da vida nacional e da cultura local. Aparecem a "República" e o "Brasil", tomando banho de sol nas areias de Copacabana - ela, com um chapéu em forma de lula, que joga com a permanência do PT no governo federal e a obstinação do ex-presidente Lula em manterse no cenário político; o "Escândalo", sempre atento aos acontecimentos, registrados com seu celular; além da "Lei Seca", preocupada com os motoristas alcoolizados, inclusive quando o veículo em questão é uma bicicleta; o "Povo", rechaçado pelo casal governante. Em busca de Hefaísto, Dionísio e Labareda se encontram também com o agradecido "Mosquito da Dengue" e a chorosa "Perimetral", com o rejuvenescido "Micróbio da Gripe" e a legalizada "Cidade do Samba" (complexo arquitetônico destinado à produçáo de artefatos carnavalescos, ainda financiados pelo jogo do bicho e outras contravençôes), com "Copacabana", com os índios da Rio+20, com o "FDP" - o Futuro Do Prefeito, e com uma "ecochata" ${ }^{11 "}$ colombiana,

${ }^{10} \mathrm{O}$ texto por nós utilizado foi-nos gentilmente fornecido pela autora. A versão registrada na Biblioteca Nacional, enorme, serviu de base para a criação do espetáculo. A estrutura da peça e a dramaturgia do espetáculo encenado no Teatro Carlos Gomes (Rio de Janeiro, out. 2011/fev. 2013) são da autora, que admitiu algumas piadas propostas pelo elenco. O texto é, portanto, diferente do que foi colocado em cena, fato comum à liturgia cômica, pois "o texto em cena, para ser vivo, é uma experiência de oralidade imediata” (BRANDÁO, s.d.).

${ }^{11} \mathrm{O}$ termo é uma gíria que define pessoas defensoras de ideais ambientalistas extremados, irredutíveis a negociaçôes. Entram na categoria dos "chatos", porque vigilantes e obstinados, capazes de açōes temerárias, "em prol do planeta". 
preocupada em decorar as novas regras da sustentabilidade. Tudo se passa, em meio à explosão de bueiros, marchas de todos os tipos, à revitalização do Cais do Porto e da Lapa e a discursos políticos.

A malandragem e o misticismo religioso, estereótipos do carioca, póem em relevo o território de exclusão por onde o tema do autoexílio, transita, por meio de personagens locais e estrangeiras (gregas), atuais e antigas, deuses e mortais, conaturalizando situaçóes cotidianas e excepcionais, o real e o mitológico - todos carnavalizados, imbricados indiferenciadamente, invisíveis e irrecuperáveis, como outros grupos de autoexilados das metrópoles - das cracolândias, dos guetos de funkeiros, gays etc. -, os "intratáveis" (ROSA; VICENTIN, 2010; SANTOS, 2013).

Do ponto de vista formal, a peça incorpora procedimentos da comédia antiga, como o entreato nos moldes da parábase aristofânica, em que entram em cena personagens alegóricas representando os teatros do Rio de Janeiro (o SESC Copacabana, o Teatro Clara Nunes, o Carlos Gomes), para fazer a crítica social das artes cênicas na cidade e apontar as casas de espetáculo elitistas (Teatro Casa Grande), que nem pisam num teatro municipal como aquele em que a peça está sendo encenada (Teatro Gláucio Gil, popular, nem fala), bem como retaliar as políticas públicas, a Lei Rouanet e os métodos de proteção e/ou prejuízo às artes.

Como se vê, O Olimpo carioca é uma criação atual, fundamentada na tradição. $O$ ressurgimento extemporâneo da comicidade fantasista, mitológica, excita a encenação informal, a enunciação de problemas, crenças e descrenças, "sem papas na língua”. A peça é uma comédia e tanto. De tanto rir, caem todas as máscaras.

\section{Cai o pano}

As obras aqui focalizadas, valendo-se de mitos da herança greco-latina, demonstram a proeminência ancestral do tema do exílio para o teatro, e sua presença, na dramaturgia brasileira das últimas três décadas.

O exilado, que tem uma vida dupla, vive a hendíade do aqui e do lá, nem aqui nem lá, presente e ausente, concomitantemente multipresente e em nenhum lugar (JANKÉLÉVITCH, 1992, p.126), já traz em si algo de personagem dramática. Propende ao teatro e ao tratamento mítico, seja pela paradoxal mobilidade para a qual a situaçáo exílica aponta, seja pelo desmesurado, sobrenatural poder que ela encena.

O teatro brasileiro dos últimos trinta anos confirma que o antigo 
e o novo mais produtivamente se comunicam, mantidos como nãocontemporâneos e heterogêneos. Por isso podem dialogar, trocar entre si, espelhar-se, diferenciar-se, dialetizar-se, retro- ou prospectivamente alimentar a história e o próprio mito. Assim funciona o teatro de tema mítico, como o tiroir à double entrée de que fala Espagne (1999, p. 78), não apenas cenário por onde transitam elementos interculturais, mas a partir do qual "itinerários da memória" podem ser percorridos (ESPAGNE, 1999, p. 138).

Em outras palavras, tomamos as peças aqui comentadas como exempla para nossa hipótese: a de que o teatro moderno de tema clássico constitui um significativo e eficiente canal de transferência cultural não apenas de repertório temático, mas de valores, questôes, imagens, crenças, modos de representação.

Se a cada reescritura de um mito ou passagem da historiografia grecolatina corresponde uma reavaliação do presente em que a peça vai ao palco, deve-se levar em conta, também, que a seleção do tema antigo se dá em funçáo dos quadros de referência do presente, e é de acordo com este código cultural que o texto antigo se vê transferido.

Através desse raciocínio, defendemos uma nova abordagem, que leva em conta um terceiro espaço de concentraçáo de sentidos: entre o universo de partida de um tema e o contexto de acolhimento, encontra-se um lugar de imbricaçôes culturais especialíssimas, não materializadas na forma de instituiçôes, técnicas ou hábitos, mas em materiais trans-históricos. O "trans-histórico" se aplica à irrupção de formas de expressão e de padrôes de sensibilidade reincidentes em épocas históricas ulteriores àquela específica em que foram produzidas. Náo se eleva acima da História, nem equaliza diferenças. Ao contrário, trabalha no interior da História, superando as cadeias de causalidades e a ilusão das continuidades.

O conceito é operatório na articulação do local e do universal, do atual e do intempestivo, do particular e do mais geral, da ordem do humano. Encontram-se aí também as intermitências culturais e os signos intempestivos de um outro tempo, que se disjunta do mundo em que ele acontece. Essa disjunção com relação ao tempo indica que o mundo não é homogêneo, nem há contemporaneidade absoluta: o passado pode avançar, e o presente recuar, movimentos temidos pela História, mas que a arte sabe manejar. 


\section{Referências}

BASSNETT, S. Estudos de traduçáo: fundamentos de uma disciplina. Tradução V. de C. Figueiredo. Lisboa: Fundação Calouste Gulbenkian, 2003.

BENDER, I. Trilogia perversa, 1826-1941. Porto Alegre: Editora da UFRGS, 1988.

CAMPOS, H. Metalinguagem \& outras metas. São Paulo: Perspectiva, 1992.

DIDI-HUBERMAN, G. A Imagem sobrevivente. Tradução V. Ribeiro. Rio de Janeiro: Contraponto, 2013.

ESPAGNE, M. Les Transfers culturels franco-allemands. Paris: P.U.F., 1999.

HOLANDA, S. Visão do paraíso: os motivos edênicos no descobrimento e colonização do Brasil. Sáo Paulo: Companhia das Letras, 2010.

HUTCHEON, L. A Theory of adaptation. New York/London: Routledge, 2006.

JANKÉLÉVITCH, V. La Nostalgia. In: PRETE, A. (Org.). Nostalgia, Storia di un sentimento. Tradução C. Agostini, A. Prete e A. Serra. Milão: Raffaello Cortina, 1992. p. 119-176.

JOBIM, J. L. Trocas e transferências literárias e culturais: do nacional aos blocos transnacionais. In: (Org.). Trocas e transferências culturais: escritores e intelectuais nas Américas. Niterói: EdUFF; Rio de Janeiro: De Letras, 2008. p. 13-112.

NUÑEZ, C. F. P. A Tradição clássica no Brasil. In: GRAMMATICO A., G. et al. América Latina y lo clásico. Tomo I. Santiago de Chile: Sociedade Chilena de Estudios Clásicos, 2003.

RODRÍGUEZ MONEGAL, E. Carnaval/Antropofagia/Paródia. In: . Sobre a paródia. Rio de Janeiro: Tempo Brasileiro, 1980. p. 6-17.

RODRÍGUEZ, S. CALASANS. Canto/Contracanto/Paródia. Revista de Humanidades e Tecnologias, ULHT, Lisboa, n. 6/7/8, p. 238-246, $2001 / 2002$. 
ROSA, M. D.; VICENTIN, M. C. Os intratáveis: o exílio do adolescente do laço social pelas noçóes de periculosidade e irrecuperalidade. Revista psicologia política, São Paulo, v. 10, n. 19, jan. 2010.

SANDERS, J. Adaptation and appropriation. New York/London: Routledge, 2006.

SANTOS, B. S. Pela máo de Alice: O social e o político na modernidade e na pós-modernidade. Coimbra: Almedina, 2013.

SENNA, P. Ismene, princesa de Tebas. Rio de Janeiro: Aeroplano, 2013.

TODOROV, T. A Conquista da América: a questão do outro. São Paulo: Martins Fontes, 1989.

WARBURG, A. A Renovaçáo da Antiguidade Pagã. Tradução M. Hediger. Rio de Janeiro: Contraponto, 2013.

ŽIŽEK, S. Hollywood Today: Report from an Ideological Frontline. 2010. Disponível em: <http://www.lacan.com/essays/?page_id=347>. Acesso em: 20 jun. 2014.

Carlinda Fragale Pate Nuñez - nunez@unisys.com.br

Manuscrito recebido em 26 de maio de 2015 e aceito em 26 de junho de 2015 